\title{
An Analysis of Jargon Used on Facebook Found in Account "Mark Zuckerberg"
}

\author{
Yuni Kartika ${ }^{1}$, Ainur Rohmah ${ }^{2}$, and Dwi Andriani ${ }^{3}$ \\ Pendidikan Bahasa Inggris STKIP Nurul Huda Sukaraja \\ yunikartika2734@gmail.com
}

\begin{abstract}
This study discusses An Analysis of Jargon Used on Facebook Found in account "Mark Zuckerberg". Hopefully, this study useful for students of English Education, particularly to help them understand the jargon that is used in social media especially on Facebook. The goal of this study to find out the jargon used by "Mark Zuckerberg" in account Facebook. This analysis used the descriptive method because it is to describe the jargon meaning in the "Mark Zuckerberg" account on Facebook. The procedure of collecting the data are: (1) Reading and finding the status of "Mark Zuckerberg" account, (2) Identifying the jargon used in the status, (3) Marking and finding the meaning of jargon found in the status, and (4) Concluding the data analysis. Based on the finding, the writer found Fifteen jargons, ten jargons abbreviation, one jargon phrase, three jargon words, and one jargon acronym in the edition of January till May in 2020.
\end{abstract}

Keywords: Analysis, Linguistic, Facebook.

\section{INTRODUCTION}

English is an international language used by people to communicate in the world. Based on Cook, Cited in Nasrudin (2012:1) "English is used for communication among nations and has become one of the most important languages in the world." because of the importance of English, the Ministry of Education in Indonesia has designated English as one of the subjects taught in School. To develop the student's' language skills. Based on Algeo (2010:1), "English has become the most widespread language in the world, used by more people for more purposes than any other language on Earth How English changed from several tribes to international languages." It means English is an international language used by many different people in the world. Students can learn English anywhere, in the classroom or the home.

Everyone wants to communicate and knows other people and everybody have a different purpose, economic conditions, and they also have a difference in language. Differences in language because of language variety. According to Trask (1999:333), the existence of observable differences in the way language is used in speech communities. The language will develop based on the growth and development of social life in which everyone used it to the community. However, language is not static. Language can change according to user want or need and want. Language has build mechanisms of change in the structure. For example, in social media, we found many languages, especially on Facebook.

Facebook is a social networking service that was originally published as FaceMash in July 2003 and then changed its name to Facebook on February $4^{\text {th }}, 2004$. The founder of Facebook is Mark Zuckerberg. Membership on the website was originally only for Harvard students but then expanded to the Ivy League campus in Boston. Then developed in the United States and Canada, and in September 2006 includes all people who have an email address and minimum age 13 years.

Facebook is defined as an online social network where users can create profiles, share information about themselves or others. Facebook has gained popularity because it is loved by users. For example, highlighted that Facebook can be used to get information, learn how to do things, generate ideas, get friends, and get someone to do somethings this statement by Dhoiloka, Bagozzi, and Pearo 
(2004).

There are many variations of the language found on Facebook, the one is jargon. The study of jargon is an important section of sociolinguistics studies. This shows a lot more about how the language community exists in our country and members o Facebook. The jargon used by the community who create it. Jargon usually grows rapidly until it is used and understood by the community. It was created suddenly without any prior plans.

Jargon is sometimes described as being a bad language as it can be misunderstood not understood at all. Politicians use jargon to cover the truth, manipulate, advertising companies are enchanted by the power of jargon to sell products and people in power exploit jargon for its ability to penetrate the minds of crowds. Others call jargon a language of professions or intelligible talk. Jargon does not consist of more words; it is always connected with societies, cultures, and subcultures. Jargon lives and talks through different professions and even if it may lead to misunderstandings, we should embrace jargon as a variety of language that enriches our vocabulary and makes our communication more effective.

There are four kinds of jargon. The first is a word, words are languages that have meaning when spoken or written by someone. Second is a phrase, phrase is a word that stands together as a conceptual unit, usually forming clause component. The third abbreviation, the abbreviation is the shortened of a word. The last is an acronym, it's an abbreviate of the initial letter from another world and is pronounced as a word.

The writer chose Mark's account because he is such an inspiring person. With his competence in world technology, he was able to set up an online-based site, namely Facebook. He is the founder and CEO of Facebook. And his Followers realize 116.859.897 people.

Based on the explanation above, the writer is interested in conducting a study "An analysis of jargon used on Facebook found in account "Mark Zuckerberg".

\section{Concept of Facebook}

Facebook is a social media that is loved and widely used by humans. Because from Facebook we can get information, friends, share stories that we experience for example certain moments, and also give greetings to friends such as birthdays, weddings, graduations, successes, congratulations, and others. Facebook even becomes one of the media used by business lovers, they can promote their merchandise on Facebook. Such a statement by Mazer, Murphy, and Simonds (2007) "Facebook is used as a medium to create and enhance online relationships between students and faculty in the academic community".

Facebook presents a social networking service where users can interact with other users. Such as the statement of Hornby (2010:525), Facebook is a social networking website. Besides, users can also upload various information about themselves so that other users can find out the information to get to know the account owner and can also comment on various things such as status posts or other information that they share. Such a the statement by Mardiana Wati and A.R Rizky Facebook is a social network that can be used by users to get to know each other and communicate and also be recreation.

Based on the explanation above, it can be concluded that Facebook is not only one of the media used to update status or to get friends but can also do business because we can promote the things that we sell. So Facebook has an important role for its users.

\section{Concept of Linguistic}

Linguistics is the science of language. And the object of study is language. Linguistics is the science that focuses on language and its use as a tool. According to King (1984), Linguistics deals with human language as a universal and recognizable part of human behavior and abilities. Based on Hornby $(2010: 866)$ linguistics deals with language or the scientific studies of language. From the various definitions of the experts, it can be concluded that Linguistics is the basis for the scientific study of human language from various aspects, including sounds, words, and grammar rules, or it can 
be defined as the study of language, and language as the object of study.

\section{Concept of Jargon}

Jargon is a variation of language created by people for a specific function, they are the ones involved in it regularly. According to Hornby (2010:801), jargon is a word or expression used by a particular profession or group of people and is difficult for others to understand. So, people in certain groups or communities use jargon for various purposes. Jargon usually means the specific language of a group. Like the example of health, they have special terms known only to those who work in that field. However, When people write for the general public, the general reader avoids jargon and uses terms that are intended for everyone. Jargon is used as a label for specific vocabulary for a particular field. Other groups or communities that want to see the language must learn first.

The language often can't be understood in the general society or people outside the group. For example in the jargon of Facebook likes COD (Cash on Delivery), KEPO (Knowing Everything Particular Object), etc. People know about these words but are still, confused as to what their meaning is because jargon consists of technical words used by certain people in a certain social or professional group. The jargon is used to communicate and interact with people in one group in society.

\section{Forms of Jargon}

Based on the statement of Halligan (2004), there are four forms of jargon. Namely words, phrases, abbreviations, and acronyms.

a. Word

Word is a unit of language that people can apply if they are spoken or written themselves. Based on the statement of Richard et all (1985: 311), a word is defined as the part of a linguistic unit that can appear by itself in speech or writing. Meanwhile, Finch (2000: 132) states that a word is a unit of expression that is recognized orally by native speakers in both language and writing. An example, form of jargon word in medicare Acute (Acute is a term that describes a condition or disease that occurs suddenly. Usually occurs in a short time and indicates a serious problem, and requires immediate treatment), Diagnosis (Diagnosis is the determination of the type of disease under investigation through the symptoms that occur. This word is commonly used by doctors when carrying out a person's health check. After the diagnosis is obtained, usually the doctor will make a prognosis).

b. Phrase

Phrases are small groups of words that stand together as conceptual units, usually forming clause components. According to Finch (2000: 112) says a phrase is a syntactic unit that usually consists of more than one word and is an intermediary between the word and the level of the clause in a sentence. The example of jargon phrase in medic such as Diarrhea (diarrhea is a disease that causes sufferers to have frequent bowel movements, with watery stools. In general, diarrhea occurs due to food and drink exposure to viruses, bacteria, or parasites), Influenza (influenza is an inflammatory reaction to the respiratory tract caused by a viral infection).

c. Abbreviation

Sudaryanto (1985: 230) defines that abbreviation is the result of the abbreviated unit. The way of shortening takes the first syllable of the words. Meanwhile, Halligan (2004) states that abbreviations are shorter forms of words, phrases, etc. by removing letters or using only the first letter of each word. For example, jargon abbreviation form in medics is HIV (Human Immunodeficiency Virus) is a virus that attacks the immune system which further weakens the body's ability to fight infection and disease. AIDS (Acquired Immune Deficiency Syndrome) is a syndrome or a collection of symptoms that arise due to a very weak immune system. Infection, which should not be severe in normal people, can be deadly in people with AIDS. 


\section{d. Acronym}

Acronyms are abbreviations that are formed from the initial letters of another word and are pronounced as a word. According to Bauer (1998: 39), acronyms are words that are created from the initial letters of words in abbreviations which are formed by taking the initial sounds (letters) of the words from a phrase and putting them together into a pronounced word. An example of jargon acronym in medics are Akper (Akademi Keperawatan/nursing academy) is an educational institution that is active in the health sector with a specialty in the field of nursing. Nursing is a profession that essentially focuses on the care of individuals, families, and communities in achieving, maintaining, and healing optimal and functioning health, AKBID (Akademi Kebidanan/Midwifery Academy) is academy level health education (Diploma III Program) with a specialization in studying the field of midwifery.

\section{METHODOLOGY}

In this study, the writer used the descriptive method. According to Ratna (2004), cited in Sopa (2015: 24): "The Descriptive analysis method is done by describing the facts then followed by analysis". Meanwhile, Ethridge (2004:24) state descriptive research may be characterized as simply the attempt to determine, describe or identify what is, while analytical research attempts to establish why it is that way or how it came to be. Furthermore, Denscombe (2010:237) explains that qualitative research uses words or visual images as the unit of analysis.

According to Kothari (2004:2-3), descriptive research includes surveys and fact-finding questions of various kinds. The main purpose of descriptive research is a description of the current situation. The main characteristic of this method is that the researcher does not have control over the variables; just only reports what has happened or what is happening.

Based on the definition above, this study describes jargon on Facebook that is used by everyone in the world. The writer is used jargon analysis to analyze the jargon meaning in account Mark Zuckerberg.

Data in this study divided into primary sources and secondary sources. They are as follows 10 The primary data source is the jargon used on Facebook found in account "Mark Zuckerberg" and 20) The secondary data source consists of other data related to the study such as the Oxford Advanced Learners Dictionary, article, thesis, internet, and other relevant information.

Facebook is one of the social media used by Mark Zuckerberg to upload something that he wants to show to other users. The posts analyzed by the writer began from January till May in 2020. And the writer has found 15 jargons. In this study the writer used documentation. And the procedure of collecting the data are: (1) Reading and finding the status of "Mark Zuckerberg" account, (2) Identifying the jargon used in the status, (3) Marking and finding the meaning of jargon found in the status, and (4) Concluding the data analysis. To conclude the data is defining about kinds of jargon then explaining it. In addition, this study focused on the jargon meaning by using a qualitative study with a descriptive method. The writer analyzed in the following steps. Firstly, reading status. Secondly, find out the jargon. And finally is explaining about jargon meaning from the status.

\section{RESULT AND DISCUSSION}

The data of this study are on Mark Zuckerberg account Facebook. The writer analyzed the data from collecting some posted on this account. After collecting the data, the writer analyzed it according to the study focuses. The writer only focused on jargon. The data has been found can be seen in the table below:

Table.1

Data of Jargon on Account Facebook "Mark Zuckerberg"

\begin{tabular}{|l|l|c|c|}
\hline No & \multicolumn{1}{|c|}{ Data } & Forms of Jargon & Date \\
\hline 1. & Update & Word & January, $29^{\text {th }} 2020$ \\
\hline 2. & AR (Augmented Reality) & Abbreviation & January, $29^{\text {th }} 2020$ \\
\hline 3. & VR (Virtual Reality) & Abbreviation & January, $29^{\text {th }} 2020$ \\
\hline
\end{tabular}


Yuni Kartika ${ }^{1}$, Ainur Rohmah ${ }^{2}$, and Dwi Andriani ${ }^{3}$

\begin{tabular}{|l|l|c|c|}
\hline No & \multicolumn{1}{|c|}{ Data } & Form of Jargon & Date \\
\hline 4. & PC (Personal Computer) & Abbreviation & January, $29^{\text {th }} 2020$ \\
\hline 5. & CEO (Chief Executive Officer) & Abbreviation & February, $03^{\text {rd }} 2020$ \\
\hline 6. & WHO (World Health Organization) & Abbreviation & March, $03^{\text {rd }} 2020$ \\
\hline 7. & CDC (Centers Disease Control) & Abbreviation & March, $03^{\text {rd }} 2020$ \\
\hline 8. & Covid-19 & Word & March, $03^{\text {rd }} 2020$ \\
\hline 9. & FDA (Food and Drug Administration) & Abbreviation & March, $10^{\text {th }} 2020$ \\
\hline 10. & PPE (Personal Protective Equipment) & Abbreviation & March, $24^{\text {th }} 2020$ \\
\hline 11. & macOS (Macintosh Operating System) & Acronym & April $02^{\text {nd }}, 2020$ \\
\hline 12. & Desktop & Word & April $02^{\text {nd }}, 2020$ \\
\hline 13. & SARS (Severe Acute Respiratory Syndrome) & Abbreviation & April, $17^{\text {th }} 2020$ \\
\hline 14. & PCR (Polymerase Chain Reaction) & Abbreviation & April, $29^{\text {th }} 2020$ \\
\hline 15. & Live stream & Phrase & May, $21^{\text {st }} 2020$ \\
\hline
\end{tabular}

Based on the table above, can be seen there are 15 jargons found. From the 15 data, the most common is the jargon abbreviation. The data is in the form of 3 jargon words, 10 jargons abbreviation, 1 jargon phrase, and 1 jargon acronym.

The writer discussed the data of jargon found on Facebook in the account of Mark Zuckerberg. The writer analyzed the jargon forms based on using Halligan's theory (2004) and also discussed the way of using jargon found on Facebook in account "Mark Zuckerberg" based on Kothari's theory (2004:2-3). Based on the findings the writer found fifteen jargons that were used by Mark's in edition January till May 2020.

\section{Abbreviation Form}

1) AR (Augmented Reality)

Is a means that can change the user's perception of reality. AR is applied to computers and cellphones. For example, the filter on the camera.

2) VR (Virtual Reality)

Virtual Reality is a technology that is simulated by a computer so that it can make users feel like they are in the environment. In Indonesia, virtual reality is known as virtual reality. For example, FPS (First Person Shooter) is a game that can make users feel like they are in the game.

3) PC (Personal Computer)

PCR is a method of examining the SARS Co-2 virus by detecting viral DNA. This test will get results for whether a person is positive or not for SARS Co-2.

4) CEO (Chief Executive Officer)

CEO is the highest position in a company that is responsible for the development of the company is led. CEO is also known as a manager.

5) WHO (World Health Organization)

World Health Organization is a United Nations agency that acts as an international public health coordinator. WHO has the main task of fighting infectious diseases such as influenza and HIV. As well as non-communicable diseases such as cancer and heart disease. WHO's goal is to ensure that all people are guaranteed health on a universal scale. Protects more than one billion people from health emergencies. As well as providing better health and well-being.

6) $\quad \mathrm{CDC}$ (Centers for Disease Control)

Department of Health and Public Service agency in the US-based in DeKalb County, Georgia adjacent to the Emory University campus and east of Atlanta. This agency serves to improve public health and safety by providing health and health information. CDC focuses on the prevention and control of disease for the healthy United States.

7) FDA (Food and Drug Administration)

FDA is an institution that oversees the distribution of drugs, food, supplements, and medical and cosmetic products in the United States. The FDA is obliged to regulate food, dietary 
supplements, pharmaceuticals, vaccines, pharmaceutical products, blood transfusions, medical devices, radiation therapy devices, veterinary products, and cosmetic products in the United States.

8) PPE (Personal Protective Equipment)

PPE is a device that has the function of isolating part or all of the body to protect a person from potential hazards in the workplace. These tools can be in the form of glasses, helmets, gloves, etc.

9) SARS (Severe Acute Respiratory Syndrome)

SARS is a severe respiratory infection accompanied by gastrointestinal symptoms caused by the coronavirus. Symptoms of SARS are known to be malaise, myalgia, fever, and followed by respiratory symptoms such as coughing with difficulty breathing. The symptoms can also be accompanied by diarrhea. These symptoms worsen a few days later with viremia, 10 days after onset. The cause is a coronavirus. SARS is transmitted through close contact, for example when caring for someone, living in one house with or direct contact with secretions/body fluids from a suspect or probable sufferers. It is thought that the main mode of transmission is via droplets and possibly through contaminated clothing and equipment.

10) PCR (Polymerase Chain Reaction)

$P C R$ is a term used in a medical examination method to determine the presence of Covid-19 in a person's body. PCR is a method of examining the SARS Co-2 virus by detecting viral DNA. This test will get results on whether a person is positive or not for SARS Co-2.

\section{Word Form}

1) Update

The update is a command used to update programs, usually found in software such as antivirus, GOM, Mozilla Firefox, games, and others.

2) COVID-19

Covid 19 is a disease caused by a virus that first appeared in Wuhan China on December 31st, 2019. This virus is transmitted through sputum droplets from the respiratory tract, for example, when in a crowded closed space with poor air circulation or direct contact with droplets.

3) Desktop

The desktop is the overall display screen consisting of icons arranged for easy identification of application programs. Or it can be called the main screen of a computer.

\section{Phrase Form}

\section{Livestream}

Livestream is video content that is broadcast live over the internet where you don't need to do editing and post-production. You just need to turn on the camera and start recording whenever you want. Besides, Livestream is interactive so that your audience can immediately leave comments and reactions during your video. Not only that, but your account followers will also get a notification every time you start Livestream. Usually, the video will also be saved immediately so that the video can be watched again when you are done with Livestream. That way, people who missed your video can watch it too.

\section{Acronym Form}

macOS (Macintosh Operating System)

macOS is Apple Inc.'s first GUI operating system. Used to operate the Macintosh computer. This macOS operating system is the first to use a GUI or Graphical User Interface. Besides being able to be used on computer devices, macOS can also be installed on smartphones or other gadgets according to applicable regulations or specifications. 


\section{CONCLUSION}

The writer concluded that linguistics is the science of language. A language is a tool for communication. Language has many varieties, one of them is jargon. Jargon is a language variety that is used by certain social groups or professions and doesn't understand by the other groups. Word, phrase, abbreviation, acronym are forms of jargon. And in the discussion, the writer discussed jargon.

Based on the discussion of the findings in chapter IV, the writer concluded that much jargon many used by Mark on Facebook. Having discussed the data, the writer found that the jargon used in the account Facebook of Mark Zuckerberg. They are 1) Update, 2) AR (Augmented Reality), 3) VR (Virtual Reality), 4) PC (Personal Computer), 5) CEO (Chief Executive Officer), 6) WHO (World Health Organization), 7) CDC (Centers for Disease Control), 8) COVID-19, 9) FDA (Food and Drug Administration), 10) PPE (Personal Protective Equipment), 11) macOS (Macintosh Operating System), 12) Desktop, 13) SARS (Severe Acute Respiratory Syndrome), 14) PCR (Polymerase Chain Reaction), 15) Livestream.

\section{REFERENCIES}

Burn,SN and Grove, SK. (2003). Understanding Nursing Research. Philadelphia: Saunders.

Chomsky, Noam. (2002).Syntactic Structures. Berlin: Mouton de Gruyter.

Diana, K.S, Malikatul Laila, \& Nur, Hidayat. (2012). A Syntactic Analysis of Noun Phrase In The Text of Developing English Competencies Book For X Grade of Senior High School. Article. Muhammadiyah University of Surakarta.

Junaid. (2018). A Syntactic Analysis of The English Noun Phrase (A Study at The Fifth Semester of English Department Faculty of Teacher Training and Education University of Muhammadiyah Makassar). Article. University of Muhammadiyah Makassar.

Moleong. Lexy, J. (2002). Metodologi Penelitian Kualitatif. Bandung: PT Remaja Rosdakarya.

Prastowo, P. (2009). Pintar Mengolah Kalimat (sentence) Bahasa Inggris. Jogjakarta: Tunas Publishing.

Algeo, J. (2010). The Origins and Development of the English Language. United State.

Alwasilah, A. Chaedar. (1985). Linguistik L. Bandung: Angkasa.

Alinda, eni Syafyahya. (2007). Pengantar Sosiolinguistik. Bandung: PT Refika Aditama. Hornby, A. S. 2001.

Bauer, L. 1998. Introducing Linguistic Morphology. Edinburgh: Edinburgh University Press.

Blum, R., W., \& Nelson-Nmari, K. (2004). The Health of Young People in a Global Context. Journal of Adolescent Health, 35, 402-418.

Bungin, Burhan. ( 2008). Sosiologi Komunikasi. Jakarta: Kencana. (2008). Penelitian Kualitatif : Komunikasi, Ekonomi, Kebijakan Publik dan IImu Sosial Lainnya. Jakarta: Kencana.

CDC, (2015). Births and Natality. Retrieved from http://www.cdc.gov/nchs/fastats/births.htm.

Chaika, E. (1982). Language the Social Mirror. Massachusets: New bury House Publishers, Inc.

Dholakia, U. M., Bagozzi, R. P., \& Pearo, L. K. (2004). A Social Influence Model of Consumer Participation in Network- and Small- Group Based Virtual Communities. International Journal of Research in Marketing, 21, 241e263.

Finch, G. 2000. Linguistic Terms and Concepts. London: Macmillan Press Ltd.

Halligan, Nancy. 2004. A Short Course on Writing Technical Report, (Online), (http://www.technical writing course.com/index.htm I downloaded on 12 November 2017).

Hornby, A. S. (2010). Oxford Advanced Learner's Dictionary new 8th edition. Oxford University Press. New York.

Le TT and Tarafdar M (2009) Business Ecosystem Perspective on Value Co-creation in the Web 2.0 era: Implications for Entrepreneurial Opportunities. International Journal of Entrepreneurial Venturing 1(2): 112-130. 
70 | Channing: English Language Education and Literature Vol. 5 No. 2 Oktober 2020 Halaman: 63-70

Mazer, J. P., Murphy, R. E., \& Simonds, C. J. (2007). I'll See You on "Facebook": the Effects of Computer-Mediated Teacher Self-Disclosure on Student Motivation, Affective Learning, and Classroom Climate. Communication Education, 56(1), 1 e17.

Moleong, Lexy. 2006. Metodologi Penelitian Kualitatif. Bandung: Rosdakarya Oofsset.

Oxford Advanced Learner's Dictionary. Oxford: Oxford University Press.Wardhaugh, Ronald. An introduction to linguistics. Fifth Edition.

Richards, J. Platt, and Weber. 1985. Longman Dictionary of Applied Linguistics. Longman Group Limited.

Stroud D (2008) Social networking: An Age Neutral Commodity-Social Networking Becomes a Nature Web Application. Journal of Direct, Data, and Digital Marketing Practice 9: 278-292.

Sugiyono. 2008. Metode Penelitian Kualitatif, Kuantitatif, dan R\&D. Bandung: Penerbit Alfabeta. 